\title{
Monogenic interferonopathy presenting as CMV infection in infancy
}

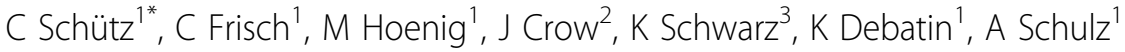 \\ From 8th International Congress of Familial Mediterranean Fever and Systemic Autoinflammatory Diseases \\ Dresden, Germany. 30 September - 3 October 2015
}

The patient is the 4th child of a consanguineous Turkish couple. She was diagnosed with CMV-pneumonitis at 7 months of age. In addition she presented with perniolike skin lesions of cheeks and ear lobes. Immunologically she was hypergammaglobulinemic for her age (IgG 11,5 g/l), her T-cell subpopulations, T-cell-proliferation to mitogens, number of B- and NK-cells were normal. IL2 and INFg production was diminished upon stimulation. Histology of lung tissue revealed alveolitis with infiltration by macrophages and histiocytes as well as lymphofollicular hyperplasia with activation of germinal centres.

At the age of $8 \mathrm{y} / \mathrm{o}$ the patient was diagnosed with pulmonary hypertension. She is being treated with sildenafil since the age of $12 \mathrm{y} / \mathrm{o}$ in addition to continuous oxygen. At the age of 15 years the patient presented for the first time with a vasculitic rash of arms, upper legs and feet. Immunofluorescence showed a positive lupus band. Immunologically she is persistently hypergammaglobulinemic (IgG 18,4 g/l) and has an upregulated interferon signature.

Although the presumed diagnosis in infancy was a functional T-cell deficiency, the disease course points towards a lupus-like disease with chronic pneumonitis and skin vasculitis as well as development of an antibody-profile compatible with SLE. Known genes for monogenic SLE including TMEM173 were excluded. Results of whole exome sequencing are pending.

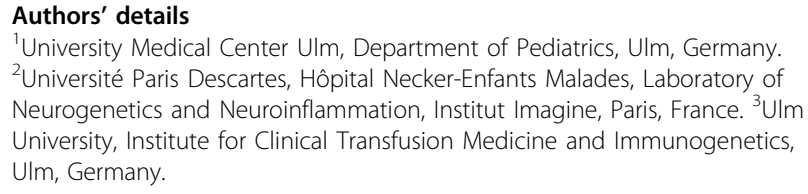

${ }^{1}$ University Medical Center Ulm, Department of Pediatrics, Ulm, Germany. ¿Université Paris Descartes, Hôpital Necker-Enfants Malades, Laboratory of Neurogenetics and Neuroinflammation, Institut Imagine, Paris, France. ${ }^{3} \mathrm{UIm}$ University, Institute for Clinical Transfusion Medicine and Immunogenetics, Ulm, Germany.

Published: 28 September 2015

${ }^{1}$ University Medical Center UIm, Department of Pediatrics, UIm, Germany Full list of author information is available at the end of the article
doi:10.1186/1546-0096-13-S1-P12

Cite this article as: Schütz et al:: Monogenic interferonopathy presenting as CMV infection in infancy. Pediatric Rheumatology 2015 13(Suppl 1):P12.
Submit your next manuscript to BioMed Central and take full advantage of:

- Convenient online submission

- Thorough peer review

- No space constraints or color figure charges

- Immediate publication on acceptance

- Inclusion in PubMed, CAS, Scopus and Google Scholar

- Research which is freely available for redistribution
() Biomed Central
C Biomed Central

C 2015 Schütz et al. This is an Open Access article distributed under the terms of the Creative Commons Attribution License (http:// creativecommons.org/licenses/by/4.0), which permits unrestricted use, distribution, and reproduction in any medium, provided the original work is properly cited. The Creative Commons Public Domain Dedication waiver (http://creativecommons.org/publicdomain/ zero/1.0/) applies to the data made available in this article, unless otherwise stated. 